\title{
Latino Communities in the United States: Place-Making in the Pre-World War II, Postwar, and Contemporary City
}

\author{
Clara Irazábal
}

Ramzi Farhat

CLARA IRAZÁBAL is assistant professor of urban planning and design in the School of Policy, Planning, and Development at the University of Southern California. In her research, she explores the interaction of politics and place-making. She is the author of Urban Governance and City Making in the Americas: Curitiba and Portland (Ashgate 2005); and the editor of Ordinary Places, Extraordinary Events: Citizenship, Democracy, and Public Space in Latin America (Routledge, 2008).

RAMZI FARHAT is a PhD candidate in the School of Policy, Planning, and Development at the University of Southern California.

We acknowledge the support of the Urban Initiative and the Immigration \& Integration Initiative at the University of Southern California for this research. We are thankful to Macarena GómezBarris, Dowell Myers, Tridib Banerjee, and the reviewers and editor of JPL, who provided helpful comments.

Abstract: Scholarship on Latino communities in the United States has yet to catch up with the rapid growth of this ethnic population in the country. Understanding the Latino urban experience and developing plans to better respond to both the needs of Latino communities and their integration within society is not only relevant, but also urgently necessary. Using the city of Los Angeles as a main lens, in addition to a general look at the urban Southwest, we contribute to the scholarship on the subject with a review of literature on Latino communities. We structure the review as an assessment of the various challenges and opportunities for urban Latinos in the prewar, postwar, and contemporary city. Focusing on space, culture, economy, and governance, we chart the various roles both the private and public sectors play in meeting these challenges. Our reading of the literature shows that particular government actions in the economic and governance domains in the past had positive impacts on Latino integration, and we call for a similar effort today in addressing contemporary challenges. We conclude by suggesting that future planning scholarship on Latino communities engage the wider urban studies literature, focus on emerging forms of urbanization, and call on planners to sustain increased academic and practical interest in the topic.

Keywords: Latino communities; Los Angeles (LA); Southwest; culture; economy; governance; space

\section{THE STUDY OF LATINO COMMUNITIES: SPACE, CULTURE, ECONOMY, AND GOVERNANCE}

Scholarship on urban Latino communities1 in the United States has not caught up with the rapid growth of this ethnic population in the country. Yet, in a century that may become known as the 
"Latino century" in the United States, to understand the Latino urban experience and to develop plans to better respond to both the needs of Latino communities and their integration with the larger society is not only relevant, but also urgently necessary. Through the lens of the city of Los Angeles (LA) in particular, and the Southwest2 more generally, we contribute to fill this need with a review of the writings on Latino communities that aims to assess the various challenges and opportunities for the lives of urban Latinos in the prewar, postwar, and contemporary city.

Today, the Latino population in the United States is on the rise, and the larger proportion of this increase is among the ranks of city dwellers. In the 2000 census, the city of LA, for instance, was home to nearly 3.7 million people-over $46 \%$ were Latina/os. The Latino population in LA grew from $39 \%$ of the city's inhabitants in 1990 , to $46 \%$ by 2000 . Over the last four decades, the greatest migration flow into the southwestern United States has come from Latin America (particularly Mexico). This flow adds to the natural growth of native-born Latinos in the United States. In this context, questions about the effects of cultural issues on ethnic identity, and economic and governance processes on urbanization patterns, are particularly timely. Our survey of the academic literature in urban studies portrays a growing interest in these issues. From a sociocultural perspective, for example, there has been sustained interest in the role of Latino immigration on urbanization trends (e.g., Lobo et al. 2002). From an economic angle, scholars have tackled the characteristics of ethnic labor markets and the economic incentives for immigration (Light 2004). In terms of governance, attention has been paid to the role of ethnic/Latino coalitions in the workings of urban political regimes (Canton 2004). Overall, however, assessments of the place of Latinos in American society and city life vary considerably. Within these sources, we find claims of assimilation (Fuchs 1990; Michelson 2003), those of segregation sustained by the harsh realities of unequal social status (García Bedolla 2005), and even claims of the incompatibility of Latino values with those of the American mainstream (Huntington 2004). Optimists, on the other hand, argue that the multiculturalism that this diversity engenders is enriching of city life (Gilbert 2001) and holds promise for sustaining the U.S. economy as the Anglo population ages (Myers 2007).

Unlike other Latinist scholars who have adapted key concepts in urban studies today for the study of Latino communities (e.g., Méndez [2005] and Lunday [2005] on Latino New Urbanism and Peña [2003] on Latino environmental justice), we present a critical reading of a literature on "Latino communities"3 in urban studies as a holistic account of challenges, opportunities, and agents of change. We find that although much progress has occurred since the turn of the 20th century in the area of Latino empowerment, the challenges Latinos face have nevertheless persisted at the turn of the twenty-first century. Consequently, we call for a renewed commitment to achieving conditions of justice that meet the current spatial, cultural, economic, and governance challenges. Our review of the literature has led us to conclude that the socially proactive role of the federal government in previous periods, whether through the New Deal programs of the prewar city or the Great Society programs of the postwar city, was an overall boost to the fortunes of urban Latinos. Given the confluence of challenges deriving from globalization and neoliberalism, and the current polarized climate surrounding immigration reform in the United States, we argue that the marked retreat of government today through devolution and deregulation may jeopardize the prospects of Latino integration. This is especially the case in a time when there is distrust of Latino empowerment. Whether because of 
a broken immigration regulatory system, misconceptions about the effects of economic interconnectedness with Latin America (e.g., through the remittance economy or the regional trade agreements), or the ill effects of domestic economic restructuring, Latino empowerment is seen by many in the United States as a destabilizing factor, and intervention is needed to rectify these preconceptions. We conclude by suggesting that scholarship bring to focus the emerging geographies of urbanization and strengthen the connection with the urban and cultural studies literature. More importantly, we make a call for an increased engagement by planning scholars and practitioners in the study of Latino communities, and acknowledge recent efforts by the American Planning Association (APA) and the Association of Collegiate Schools of Planning (ACSP) in moving in that direction.

The focus of this article is thus on community- and place-making (which, throughout the paper, is distilled into space, culture, economics, and governance) in three specific historical periods. We rely on three sets of organizing themes. First, we tell the story of Latino communities in the three historical periods of pre-World War II, postwar, and contemporary city. Picking up the story in the early decades of the 20th century is warranted because it is then that the first largescale migration of Mexican nationals to the United States gained momentum, a movement partially driven by the maturation of the United States as an industrial powerhouse. In addition, during those early years, there was acceleration in the growth of many southwestern cities, the traditional heartland of Mexican/Latino settlement. Secondly, in each period, we disentangle four main threads of analysis: space, culture, economy, and governance.4 This exercise helps us understand the challenges that Latinos face in their struggles for spatial identity, cultural recognition, economic integration, and empowerment in governance. Finally, we reference some of the responses to those challenges by whether they have been initiated in the private sphere (including private enterprise and civil society) or that of government.

The recognition that space is socially produced (Lefebvre 1974; Harvey 1998; Massey 2005) acknowledges that the way people think about space affects their understandings of the world and, in such, their politics. A survey of Latino communities from the twentieth to the twenty-first centuries reveals that many forces in aggregate effect exacerbated the condition of "barrioization" of their communities (Villa 2000). Barrioization, a term coined by Camarillo $(1979,53)$ and expanded by Villa $(2000,4)$, is understood "as a complex of dominating social processes originating outside of the barrios" 5 that contributed to the formation of residentially and socially segregated Latino neighborhoods. Conversely, the term "barriology" was coined to denote the community-sustaining practices that re-create and re-imagine "dominant urban space as community-enabling place" (Villa 2000, 6). For Latino communities, the struggle for spatial identity has proven to be an effective means for attaining cultural recognition, economic integration, and governance empowerment.

The cultural perspective allows us to outline how Latino cultures juggle the forces of homogenization and acculturation. For pioneer scholars, the Latino neighborhood or "barrio" was perceived as a positive influence for solidifying the sense of communal identity (Griswold del Castillo and de León 1996). This early scholarship capitalized on traditional themes in the study of city culture, mainly the compositionalists' thesis that the study of city life needed focus on social networks and their evolution as a window to understanding social stability (Gans 1968). The liability of this approach was that it did not properly account for agency and cultural 
evolution (Waldinger 1996). Revisionist scholarship today redresses these shortcomings by painting a picture of dynamic, evolving Latino cultures mediating the forces of assimilation and cultural assertion (Sanchez 1993; D‘Avila 2004). Recently, the post-structuralist turn in the study of the city has shifted focus from the macro to the micro, or as M. P. Smith $(1992,496)$ elaborates, "from laws of assimilation and identity to the cultural construction of needs, interests, [and] forces." In the literature on Latino communities, recent writings that emphasize the culture of the barrio (e.g., Cuéllar 2003; D’Avila 2004) fall into this vein. Accomplishments in the arena of cultural recognition have helped Latino communities expand their spatial identity, economic integration, and governance empowerment.

The economic perspective allows us to contextualize the challenges facing Latino communities today under conditions of neoliberalism and globalization. Latino communities have always tended to be relatively underdeveloped in the standards of economic prosperity (see e.g., Dohan 2003). In this sense, class struggle (Romo 1983) and "proletarianization” (Villa 2000) remain popular themes. Many recent analyses have been written in the spirit of neo-Marxism, emphasizing how urbanization facilitates production under capitalism (Harvey 1999) and insures the social reproduction of labor (Castells 1977), and how planning becomes a tool of political struggle (Jaret 1983; Mollenkopf 1983). Valle and Torres (2000), for example, describe how the spatial convergence of capital, politics, and class in the formation of Latino communities has been a formula for the extraction of surplus labor. Some government-led planning programs, such as the urban renewal prevalent in the postwar period, are seen as forms of subjugation. Other, more radical, approaches have also been more popular. In the tradition of Franz Fanon, the Latino metropolis that took shape in the 20th century has also been linked in essence to the post-colonial uprising against forms of economic exploitation (Davis 2000). The enduring challenge of the economic integration of Latino communities into middle class socioeconomic status can be partially addressed through greater cultural recognition, spatial identity, and, most importantly, governance empowerment.

Finally, a perspective of governance in the literature on the Latino city can be distilled from the discussion on the bureaucratic vs. locally situated knowledge employed in managing the city (Arreola 2004). Aguilar San Juan (2005) identifies three types of place-making activities correlated with such institutions: territorializing, regulating, and symbolizing. Territorialization, in her words, is the social process through which spaces become "places" with specific functions. Once differentiated through territorialization, places need to be regulated, supervised, and controlled. Symbolization, which is protected by regulation, can then further differentiate places. In lines similar to San Juan's, Villa (2000) outlines three types of top-down control of the Latino city: physical regulation through the control of land use, social legal control of space through implicit and explicit discriminatory practices, and ideological control. In the face of these constraints, grassroots control has alternatively been partially advanced through the formation of local institutions of civil society that have been instrumental in resisting marginalization and subordination. These institutions have been critical in refocusing and channeling governance to the specific needs of the neighborhoods. Governance empowerment of Latino communities, both from the bottom-up grassroots groups and the top-down structures of government, is determinant to ensure economic integration, cultural recognition, and spatial identity in these communities. 
In sum, with this review, we want to shed light on the key factors that have supported spatial identity, cultural recognition, economic integration, and governance empowerment in and of Latino communities (opportunities) and the key factors that have hindered them (challenges).

\section{THE LATINO CITY PRE-WORLD WAR II: 1900-1945}

Under the terms of the Treaty of Guadalupe Hidalgo, which ended the United States-Mexico war in 1848, Mexico ceded the territory that today is California, New Mexico, Nevada, parts of Colorado, Utah, and Arizona, and it approved the prior annexation of Texas. By 1850, Mexicans in the ceded territory became U.S. citizens and thereby became the first Mexican Americans. At the conclusion of the Mexican-American war, only 50,000 Mexicans became Americans. Latinos accounted for $1 \%$ percent of the population of the United States in the year 1900, mainly concentrated in the territories annexed in 1848. By 1930, that share increased to $2 \%$ of the population. Although the population of European Americans increased 1.6 fold during that period, the Latino population increased a notable 3.7 fold to 2.4 million people (Gibson 1992). These figures can be attributed to the fact that immigration was the major driving factor in the growth of the Latino community. Restrictive immigration policy for Europeans and Asians, in addition to various wartime and market forces, drew hundreds of thousands of Mexicans to the United States during the late 19th and early 20th centuries. The need to continue constructing railroads and harvesting agricultural crops in the Southwest was met by heavily recruiting Mexicans (Ferg-Cadima 2004). The demand for agricultural labor in the early 20th century was later complemented by a shortage of industrial labor. As World War I reduced immigration from Europe to a trickle, and when Congress passed the “quota laws” (Massey 1995) on southern European immigration a few years later, Latin Americans-mostly Mexicans-found themselves in higher demand and, for the first time, were actively recruited to the northern industrial cities. Although only 50,000 Mexicans entered the United States in the first decade of the century (as in years past), more than 410,000 entered in the third decade. It was not until the Great Depression and World War II that this movement was greatly tempered.

\section{Conditions}

Space. The cultural landscape tradition within cultural geography pioneered by Patrick Geddes and Karl Saur has been influential in analyzing the early settlements of the Southwest in the scholarship on Latino communities. Richard Nostrand (1970) and later Daniel Arreola (2002) adapt these analyses of settlements within a regional perspective for the study of cultural identity. Historically, even the archetypical Spanish/Mexican urban form, the plaza-centered town, was attributed to an adaptive need for defense against raids (J. Smith 2002). Later on, in "Tejano South Texas” (Arreola 2002) and elsewhere in the Southwest, Anglo settlement and discrimination led to the formation of "dual towns," where both Mexican and Anglo sections retained their distinct commercial cores. Thus, in many ways, some of the distinctive features of the barrio today - the social use of semi-public space, the prevalence of vernacular architecture, a vibrant retail economy, and an abundance of venues for socialization (ibid, 90)—reflect a history of the struggle for survival under conditions of adversity. In effect, all aspects of southwestern life were separate and unequal for people of Mexican descent (Ferg-Cadima 2004, 6-7). 
As the Mexican and Mexican American populations grew, the Anglo majority responded by implementing segregation policies and practices. Mexican and Mexican American workers became a lesser-paid working class. They lived either in barrios or in colonias (rural shanty towns) (G. Gonzalez 1990). In the prewar period, real estate covenants prevented sale of property to people of Mexican origin (Ruiz 2003). They also had few resources and protections under the law to combat housing discrimination. De jure or de facto Latino segregation in public facilities became increasingly common from 1848 through the 1920s, and beyond (Wollenberg 1976). Segregated institutions included drugstores, restaurants, cafeterias, hotels, movie theaters, barbershops, maternity wards, bowling alleys, and hospital wards (Rangel and Alcala 1972). This segregation extended to restroom facilities and drinking fountains; stores even displayed signs reading "Mexicans and Dogs Not Allowed” (Ferg-Cadima 2004). On occasion, Mexican Americans were also lynched and denied burial in "white" cemeteries (Rangel and Alcala 1972, Perea 1997). In California, Mexicans and Puerto Ricans were barred from public parks, playgrounds, and swimming pools. Some pools limited Latino use to "Mexican day,"—which was usually Monday_-before the pools' chemical cleaning and when the water was filthiest (Montoya 2001). Children of Mexican origin also suffered from segregation in public schools throughout the Southwest. By 1930, 85\% of Mexican-origin children in the Southwest were attending either separate classrooms or entirely separate "Mexican" schools (Wollenberg 1976; Donato 1997).

In Southern California, remnants of the United States-Mexico war were still present in the social, and oftentimes spatial, division between U.S. native-born people of Mexican descent and Mexican newcomers. Many people of Mexican descent, including U.S. native-born citizens, were forcefully sent to Mexico at the onset of the Great Depression in the 1930s. Others decided to leave as race relations and economic conditions worsened in the United States during that time. This “Mexican Repatriation” program, a misnomer, affected some 500,000 Mexican Americans. Its process of racial eviction effectively emptied many Latino barrios of their inhabitants. In LA, although Mexicans shared neighborhoods with other ethnic groups, they were eventually consigned to specific areas such as Sonoratown,6 Boyle Heights, Belvedere, and Maravilla, through both formal and informal discriminatory practices (Sanchez 1993).

Later on, scholars asserted that LA's elite consciously sacrificed the Latino Eastside to industrial development (Fulton 1997; Diaz 2005). Cognizant of the contradictions and uncertainties characteristic of capitalist industrialization, the elite allowed the Eastside's space to be "shaped by destructive and creative energies unleashed in the competition between older and newer forms of capital" (Valle and Torres 2000, 22). In this industrial expanse, these single-use cities dedicated to industry developed as the "receptacle of reserve labor force" (Diaz 2005), and became the forerunners to the "maquilas" that would sprout across the United States-Mexico border in the decades to come. At the same time, the construction of "Mexicanness" as a relic of the past in the central city, exemplified in the creation of themed environments (e.g., Olvera Street in LA), the adoption of reinvented architectural styles (e.g., Mission Revival), and the fabrication of cultural festivals (e.g., the "Fiesta" theme co-opted for city parades), allowed for its benign reception in the dominant Anglo culture. In many ways, this early history of Latino settlements helped develop the tradition of resistance and adaptation to adversity that would later characterize the barrios of multi-ethnic cities of the 20th century. 
Culture. The main cultural challenge in the early decades of the 20th century was that of Americanization. As a form of conformity to the dominant Anglo-Protestant culture, this notion confronted Mexican Americans and other immigrants with assimilation pressures and challenges in defending their cultural heritage. The early industrial city of the 20th century accommodated migrants from various ethnic and racial backgrounds. In LA, for example, several neighborhoods such as Watts and Boyle Heights developed into multiethnic communities, with many southern European and religious minorities pouring in (Wild 2005). Early on, in the survival of Mexican place names and culture, Latinos felt encouraged to celebrate their native traditions (Romo 1983). In the growing barrios, propinquity helped ethnics develop a sense of identity (Romo 1983; Griswold del Castillo and de León 1996). As times progressed, family ties, a substrate enabling the formation of communal identity, also remained strong (Sanchez 1993).

But in the Southwest, segregation and racism thrived in both a cultural and intellectual milieu that tolerated it, and under the aegis of an elite that celebrated the trinity of industry, Anglo values, and patriotism (Wild 2005). Los Angeles, for instance, was conceived and marketed as a "pure," new, hopeful city, which was a continent away from the industrially, and implicitly, ethnically polluted traditional heartland. An example of this hostility is in how the recession in the later 1920s was construed in part as a "Mexican problem," where migrant laborers competed for "white jobs.” During this period, people of Mexican descent were repatriated in great numbers. It is estimated that by 1931, only one-third of the migrant workforce remained (Villa 2000). In many ways, this attitude stunted many Latino communities' quest for incorporation (ibid). According to the power brokers of the time, only when Mexicanness was "tamed" through cultural commodification could its innate danger and impurity be controlled.

Even progressive reformers negotiated the space between rejection and cooption. Although they intervened on behalf of Latinos in hopes of alleviating conditions of poverty and marginalization, this reform group carried its own paternalistic biases. The mid-western Protestant ethic, with its loathing of urbanity's vices, was the crux of the Progressive Reform Movement's ideology. That these reformers were actively involved in improving Mexican communities was, in effect, not only out of concern for the material plight of the residents. At the heart of it, the reformers were convinced that an alteration of values through assimilation would be instrumental to socioeconomic advancement (Villa 2000). For example, the reformists' “Anglofication” campaigns in 1920s LA were derogatory of Mexican culture and Catholicism (Wild 2005). Significantly, this triple approach of hostility, cooption, and "reform" was legitimized by the academic currents of the day whereby "ghetto"7 models of urbanism and the "natural" geographic distribution of the races were treated as uncontroversial ideas (Romo 1983), thus largely stunting a discussion on the socioeconomic determinants of segregation (Wild 2005).

Economy. During the development of the industrial society in the United States, Latinos shared the highs and lows of labor class struggles with other blue-collar workers, although their conditions were exacerbated by entrenched racism. There were both internal and external determinants to the conditions of labor at the time. The breakup of the large holdings of ranchos at the turn of the century made for subdividable land, which fueled a real estate boom. The industrial expansion that accompanied World War I also fueled industrialization, whereby employers reluctantly sought foreign nationals and minority workers (Romo 1983). In many cities of the Southwest and especially in California, the growth of industry through maritime 
trade and the inter-urban railway system was translated into a large demand for manual labor, which in part satiated the upsurge in supply resulting from an accelerating immigration. Although Mexicans found employment in the railroad, tire manufacturing, agriculture, and construction sectors, unions, wary of the downward push on wages they might put into effect, did not seek their enlisting. Urban growth was also not kind to the underprivileged. In LA, Mexicans were displaced from Sonoratown by the building of railway station and depots, a move facilitated by the expansion of the trolley system.

External factors were less conducive of labor empowerment. In the teens and twenties, political instability in Mexico, which precipitated economic uncertainty and violence as consequences of the revolution, further encouraged immigration to the United States. In addition, industrialization pursued in Mexico by the Diaz regime lead to new age "proletarianization" on a wide scale, which also drove immigrants north (Sanchez 1993). These events increased the pool of “disposable” labor. Many workers, unable to secure stable employment in the United States, became victims of repatriation campaigns by the time of the recession. To keep Mexicans "in their place," the occupational structure was designed in a way that prevented upward mobility by limiting the types of jobs available to non-whites (ibid). In many industries, Mexicans and Mexican Americans simply found little employment due to logistical issues such as a lack of adequate transportation means to the plants, and of course, racial prejudice (Waldinger 1996).

Governance. The challenges facing Latino communities in the early 20th century pertain to the physical, social, legal, and ideological control of Latino places. As mentioned earlier, the privatization of communal lands ended the privileges of many Mexican Americans who were dispossessed of their property (Villa 2000). Later on, local governments further enforced their land use regulation powers in ways that discriminated against the Mexican population. In this era of outright disenfranchisement, the "siege" of the Latino community took many forms (Acuña 1984). As we saw earlier, scholars contend that barrios started out as one section of dualcommunity towns (Arreola 2002). As white communities incorporated, there was an intense resistance to cities' ethnic minorities descending down the same path of self-government (N. Rodriguez 1993). As we saw, this resistance took on even more sinister dimensions as entire communities were sacrificed to industrial development. Business interests incorporated "single use cities," and used "mono-functional zoning” to carve out cities of industry in and around Latino communities in such a way that residents would not be able to control the adverse environmental impacts of growth, among other liabilities (Villa 2000). For Valle and Torres (2000), this accounted for nothing less than "economic gerrymandering." Latinos in this system would come to constitute the "reserve labor force" that would weather the fluctuations in capitalist boom-bust cycles (ibid, 41).

Also prevalent during this period was the abuse of policing authority. A portrait of the abusive policing of the LA barrios can be painted across many seemingly unrelated episodes of violence and repression. From the repression of the Flores Rebellion of 1857 (Villa 2000), to the 1931 immigration raid on the plaza district, an impressive array of policing tools, such as prostitution districts, no speech zones, and anti-miscegenation laws were used to subdue Latinos (Wild 2005). The LA Police Department (LAPD) liberally enforced laws against minorities, earning a reputation for racism. During the teens and twenties, the Espionage Act was interpreted by federal authorities as a license to harass Mexicans in the United States (Romo 1983). The 
housing policies of the federal government, such as the Federal Housing Administration's discriminatory underwriting guidelines, also substantially limited Latino mobility (Diaz 2005). For those who qualified for public housing after it was instituted in the years following the Depression, widespread practices by housing authorities to channel residents into segregated projects also exacerbated the barrio phenomenon (Wild 2005).

\section{OPPORTUNITIES: ADDRESSING THE CHALLENGES OF THE PRE-WORLD WAR II LATINO CITY}

In the early 20th century, agents in the private sphere initiated a host of efforts to address the aforementioned challenges. Spatially, Latinos expanded their tradition of self-help to build networks of solidarity, which through collective efforts, helped adapt their communities' built environments. The tradition of socialization in public spaces allowed for the creation of such networks and for the enhancement of social capital, without the purview of government. The lack of government oversight permitted Latinos some flexibility in adjusting their spatial settings. In addition, the spaces of alternative binding institutions, such as churches and activist groups, provided the community with cohesion, identity, and a sense of place and belonging. At the same time, interest in the spatial thematization and romantization of an idealized Spanish and Mexican past became popular in some Anglo communities. In San Antonio, TX, for example, Workers Progress Administration (WPA) funds were used to create Spanish and Mexican quarters such as Paseo del Rio, La Villita, and the Latin Quarter (Arreola 2004). Other examples are the thematization of Santa Barbara, CA, and Placita Olvera in LA. Although criticized for being “Anglo” visions of Mexican architectural styles and detrimental to Mexican American interests at the time, these projects survived to become emblems of the Mexican American heritage and generators of economic activity.

In the cultural sphere, the nascent Latino media and cultural and sports associations were instrumental in the discursive formation of Latino identity within spatial and cultural boundaries (Sanchez 1993; Villa 2000). Newspapers such as La Raza called for Mexican Americans to take pride in their heritage. Additionally, the roles of youth and popular culture, such as those found in music and cuisine, cannot be underestimated in the making of the Mexican American identity (Sanchez 1993). The quest for identity was particularly determined amongst the youth, whose exclusion from mainstream culture was counteracted by the formation of a unique Mexican American subculture. After the end of World War II, returning servicemen helped shape the emerging Mexican American identity by fueling a nationalism that counterbalanced the loyalty to the Mexican motherland (Romo 1983). Newly founded associations (e.g., Club Independencia in LA) also moved to assist in the acculturation of immigrants (ibid). During this time some government policies were aimed at countervailing dominant prejudices, such as President Roosevelt's Good Neighbor Policy (1933), which lead to a decline in the demeaning stereotyping of Latinos by the U.S. government, the media, and the entertainment industry (Barry et al. 2005). Meanwhile, new cultural icons such as Carmen Miranda, and Walt Disney’s popular films "Saludos Amigos" and "The Three Caballeros" created stereotypes of Latinos as sensuous, exotic, and adventurous.

Economically, this emerging Latino culture was an inspiration for activism and empowerment in the pursuit of economic justice. Groups in the vanguard against discrimination (e.g., El Congreso 
movement and the Mexican American Movement) helped nurture youth leaders and secure their employment. Eventually, as the number of minorities in the labor force increased, the labor movement courted these antidiscrimination groups to prevent further depreciation of wages. At the time, government policy was proactive in the wake of the depression, and federal intervention in the economy, often based on unbiased hiring practices, was a boost to Latino fortunes. However, the integration of minorities into the labor force did have some adverse effects for Latinos. For example, when the federal government decentralized industry for strategic purposes during World War II, African Americans followed employment opportunities to cities in the West, many of which subsequently became "racialized" to the detriment of Mexicans and Latinos (Avila 2004). This situation would be challenged in the postwar city. In many ways, however, government employment in the agencies created by the Roosevelt Administration during the New Deal tempered the disinvestment in Latino neighborhoods typical of traditional government (dis)interventions and private market strategic decisions. Also, the federal welfare program Aid to Families with Dependent Children (AFDC), which was created by President Roosevelt in 1935 as part of the Social Security bill, contributed to favor some poor Latino families (Civil Rights 2007).

In terms of governance, the official neglect of Latino interests also fostered a tradition of selfhelp leading to the development of local institutions that, in turn, helped the barrio weather social and economic storms in times to come. Some scholars (e.g., Diaz 2005) trace this development back to 19th century "mutualista” organizations. J. Smith (2002) credits these mutual aid association chapters (e.g., the Sociedad Protección Mutua de Trabajadores Unidos) with accelerating integration. To face some of these challenges in governance, a few national Latino advocacy organizations were founded in the early 20th century, particularly the League of United Latin American Citizens (LULAC), the first such organization founded in 1929, and the American Government Issue (GI) Forum. They were not law reform organizations (such as the National Association for the Advancement of Colored People [NAACP] Legal Defense Fund for African American civil rights), but they gave referrals and financial support to lawsuits seeking to protect Latino rights (Wilson 2003). This loose arrangement, however, allowed Mexican American lawyers of the early cases to choose their individual case strategies. Prior to Brown vs. Board of Education that mandated the racial desegregation of schools, they won school segregation cases relying on the argument that Latinos were "other whites," thus establishing precedents apart from similar African American cases; but since the Mexican American lawyers maintained this separate path even after Brown, "the revolution in civil rights litigation that commenced with Brown by-passed Mexican Americans until the late 1960s” (ibid, 146).

\section{THE POSTWAR LATINO CITY: 1945-1990}

In the postwar years of economic recovery on both sides of the Atlantic, European immigration finally narrowed down, while the spectrum of Latino immigration widened and continued to reinforce Latino communities. In the decades of the ' 50 s, ' 60 s and '70s, Latinos accounted for $0.8,1.1$, and 1.5 million immigrants, respectively, thus increasing their share from roughly onefourth to one-third of all immigrants. While immigration from Mexico sustained pace, 200,000 Cubans arrived in the 1960s seeking opportunity and escaping political upheaval, as did 100,000 Dominicans and 70,000 Colombians (Massey 1995). This surge helped increase the Latino share of the population to 3.5\% during that decade (Passel and Edomonston 1991). Also significant in 
this period was the migration of Puerto Ricans escaping local economic hardships, and the later immigration from Central America amidst political instability. Central and South Americans increased their share from almost 7\% of the total number of immigrants in 1960 to 12\% in 1980, helping push Latinos beyond the one-third mark of total immigrants. Mexicans still accounted for half of that figure, and Cubans for one-sixth during the 1970s and the early 1980s (Massey and Schnabel 1983). Later on in that period, as economic restructuring accelerated, traditional gateway states in the heartland and the industrial northern cities in Illinois and New York were being supplemented by newer destinations. Although Mexicans accounted for $12 \%$ of entrants to non-gateway states pre-1980, that figure rose to $25 \%$ in the later decade (Hempstead 2007). Traditional immigrant destination cities such as New York, Chicago, Philadelphia, Cleveland, and Boston decisively lost ground to other destinations such as Orange County (CA), Houston (TX), and Miami (FL).

\section{Conditions}

Space. The Southwest continued to be the stronghold for the population of Mexican origin or descent during these decades. In 1990, the region's share of the population was 83\%, but had started to decrease since the late 1980s. Some U.S. citizens and Mexicans possessing skills or connections started to look for opportunities outside the traditional Southwest region, which continued to be marked by a stark inequality for people of Mexican origin or descent (Saenz et al. 2007). Children of Mexican origin continued to suffer from segregation in public schools throughout the Southwest, even after the 1954 Supreme Court's decision in Brown vs. Board of Education mandated the end of school segregation. In fact, Latino school separation has increased since that time (Orfield and Eaton 1996; Frankenberg and Lee 2002) and is primarily a reflection of neighborhood segregation.

In LA, the postwar years helped increase the ghettoization of Latinos in some inner city neighborhoods (e.g., Boyle Heights in East LA) and inner-ring suburbs (e.g., Huntington Park and other "gateway cities") that wealthier American whites and immigrants of European descent had abandoned for other suburbs. The LA River, now a barrier made of concrete, served to segregate further Latino barrios from the downtown and upper-scale western side of the metropolis. These barrios were also traversed by freeways and subjected to urban renewal projects, which caused destruction of the urban and social fabric of the mixed-use neighborhoods, and oftentimes replaced them with commercial developments or public housing projects. Bunker Hills and Chavez Ravine became prominent examples of the negative effects of urban renewal interventions in minority communities. The rise of the white suburbs and the building of freeways eventually had the profound effect of "gutting the hetero-social city" (Avila 2004, 213). As racially homogenous suburbs emerged, centers of Latino population, such as unincorporated East LA, had little means to control demographic change. Hence, they became gateway communities for migrants and those otherwise incapable of breaching racial and economic barriers that barred them from other communities (Fulton 1997; Diaz 2005).

Culture. In the post-World War II years, the main cultural challenge for Latinos was how to defend their identity against an emerging "white" ethnicity that consolidated the various minorities of European descent into a suburbanizing middle class. Thus, the forces of discrimination in the form of segregation in inner city neighborhoods and inner suburban rings 
(particularly industrial and blue-collar neighborhoods) remained, but derived most of their strength from the vilification of city life. The pre-World War II era themes of purity and civic values became pillars for establishing the white suburban culture that later came to the forefront. In Avila's (2004) account, the enclaves of exclusive residential spaces, privatized entertainment, and consumption that are associated with suburban "white" culture, proceeded the segregationist Victorian culture and the urban industrial "mass culture" of the early decades. Social polarization also increased in this period, in many ways fueling a societal criminalization of poverty and an increased aversion to attitudes and actions that could be considered "communist." These emerging social attitudes facilitated the social construction of the barrio as an enclave of poverty and crime, with the associated prejudices against Latinos and immigrants as undeserving poor. The plan for relocating the Latino community of Chavez Ravine to modern public housing built in the same place, for example, was attacked as a communist plot that resulted in the incarceration of the planner in charge, the forceful displacement of the community, and the support of private corporate development (the Dodgers Stadium). If the segregation of the prewar city was legitimized by prejudice and academic opinion, Avila (2004) contends that popular culture played no small part in demonizing city life and popularizing the suburban ideal of the postwar city. Many cultural trends, such as the "film noir" movement based in LA, derided the urban malaise resulting from racial impurity and cultural waywardness in the city.

Economy. Although Latinos made inroads into the wider labor force in the postwar city, the main challenge for their communities was their peripheral relations vis-à-vis centers of investment, which was later exacerbated by economic deindustrialization. For example, early on and during the years of robust growth following World War II, many manufacturers fled central LA for cheaper and larger sites in outlying counties and cities. These became centers of gravity that attracted Latino labor to suburban cities such as Whittier, Montebello, and El Monte. Within LA, the suburbanization of growth meant that the Eastside would be treated as a supply of lowskill labor, but would not be a destination of investment itself. The city collected much more in taxation than it spent in Latino communities, and its expenditure was concentrated downtown (Valle and Torres 2000). In the language of neo-Marxism, this was typical of a core-periphery relation.

After a period of robust growth, a watershed process in the 1970s that had a lasting effect on the fortunes of Latinos was the gradual de-industrialization and economic restructuring precipitated, in part, by external shocks and competition. The bifurcation of the labor force and the decimation of union jobs were processes that had a dramatic impact on Latino communities. Despite some Latinos moving to outlying suburbs, the persistence of low paying jobs and the demise of a high wage-paying industrial sector were important reasons why poor barrios persisted (Yoder and Gutierrez 2004). In LA, this and the subsequent exodus of the whites were important factors in how the Eastside "colonias" coalesced into a super barrio (Curtis 2004). From 1970 to 1990, wages for Latinos actually declined (Waldinger and Bozorgmehr 1996). During this period in LA, there was a $24 \%$ decline in the number of middle-income neighborhoods (Booza et al. 2006), many of which were in the Latino Eastside. Undocumented Latino immigrants earned low industrial wages that helped employees maintain low production costs and low-priced commodities. Undocumented farmers were also used in agricultural production with meager wages and poor accommodations. Later in the 1980s, the meat and poultry processing industry 
underwent restructuring, creating low-wage jobs in rural areas of the Midwest and South, which attracted new immigrants and Latinos there (Saenz et al. 2007).

Governance. A significant governance challenge of the postwar period was the continued control of planning institutions by the business elite. Acuña (1984) described the greater Eastside of LA as essentially "under siege" through industrial zoning and freeways. Although this reflected broad-based strategic approaches to cooption and control, other more tactical means were also utilized. Dogadag (1974), for example, illustrates how the selective stringent enforcement of zoning, building, and housing codes in Latino neighborhoods and the building of housing on leased land resulted in clearing the way for displacement, a prerequisite for large-scale redevelopment or land confiscation. The disenfranchisement of Mexican American and Latino communities was, in many ways, also a battle between the imperial designs of the state and the daily needs of its local inhabitants (Valle and Torres 2000). With the rise of the Chicano social movement, this view of the vilification of planning as a technique of elite domination gained some notoriety.

The decision to beef up border control in the late 1960s also created the physical barriers between Mexico and the United States that would have a great impact on Mexican American self-identification and their subsequent, more forceful, integration into American society (Sanchez 1993). In 1970s and early 1980s, according to the history of some organizations in East LA, Latino empowerment was also challenged from within communities by organizations whose policies often coincided more with the visions of the non-Latino elite rather than the aspirations of the less fortunate Latinos (Acuña 1984). This phenomenon was also identified in New York by D’Avila (2004), who details how Enterprise Zone legislation, which allocated funds for productive activity in designated areas, consistently earmarked expenditures to organizations that the government identified with at the expense of other grassroots outfits that were more in tune with the needs of the Latino populace. In LA and other growing metropolises, wealthy communities created their own cities to prevent incorporation into the larger ones, while patches of unincorporated poor areas, such as the Florence-Firestone area near LA, remained legally disenfranchised and unclaimed.

\section{OPPORTUNITIES: ADDRESSING THE CHALLENGES OF THE POST-WORLD WAR II LATINO CITY}

In the private and civic spheres, the grassroots empowerment efforts of the prewar period culminated in the 1960s and 1970s with coordinated nationwide efforts such as the Chicano social movement, which contributed much to the reinvigoration of Latino communal pride and the formation of a narrative of value and achievement. As a discourse of deliverance and reclamation of rights (Frausto 1999), the Chicano movement was an impetus for the celebration of spatial and cultural rights in the face of calls for wholesale assimilation. In this resurgence of pride, the barrio was reconstituted, physically and discursively, as a site of resistance and celebration (Arreola 2004). The physical and social appropriation of private, semi-private, and public space furthered the assertion of cultural pride. In the growing Latino barrios, the social use of front yards, the symbolic appropriation of public space in the "muralization movement," and the cultural appropriation of the built environment through vernacular architecture proliferated (R. Gonzalez 1999; Rojas 1999; Arreola 2002). The period also witnessed a revival 
of native cultural traditions with the organization of fiestas and celebrations in public spaces (e.g., in Placita Olvera and Mariachi Plaza, LA), and in many ways these cultural events were reclaimed from appropriation after the Anglo influx to the Southwest (S. Rodriguez 2001). Local organizations also continued their roles in social development. In the wake of reduced funding for language classes and other social programs after the 1970s, churches picked up where government had left off (Moore and Pinderhughes 1993; Espinosa et al. 2005). Churches throughout the Southwest also became very active in the Sanctuary Movement, offering refuge to Central Americans displaced by U.S.-sponsored wars in their countries, and protesting U.S. immigration and foreign policy. This movement (which is recently being revived, see Irazábal and Dyrness 2007) became "one of the most important acts of resistance of the late twentieth century” (García 2005, 159).

Alternatively and on the economic front, Mexicans and Latinos benefited from the postwar boom and were eventually able to break into higher-paying occupations in light manufacturing and professional jobs (Waldinger 1996). As economic restructuring proceeded, Latinos were able to make strides as proprietors and entrepreneurs, purchasing franchises and running service outlets. Later in the 1980s, the large-scale migration from Latin America made for an increasing pool of clients for the new middle-class entrepreneurs, a case in point being the Central American community in LA. Encouraging figures show that, although in 1970, 72\% of men worked in ethnic niches, in 1990, the figure was reduced to only 20\% (Waldinger and Bozorgmehr 1996). Economically, restructuring has also been an opportunity for some Latino associations to acquire agency in the capitalist system. Grassroots and nonprofit agencies that engaged in economic activism flourished (e.g., the Southwest Network for Environmental and Economic Justice). Struggles for living wages and sustainable development were some of the headlines, and other successes in Southern California included the enforcement of air quality standards (Diaz 2005).

In the realm of government, Latinos in the postwar era engaged local politics and mustered political power that allowed them to expand and defend their rights. In LA, for example, veterans' associations carried the momentum after World War II, and placed Latino politicians on the city council. In places where they became majorities, Latinos instituted symbolic power through naming, claiming, and celebrating Latino heritage in their communities (Davis 2000). More importantly, civil rights era reforms delegitimized the multifaceted discrimination against Latinos in employment, housing, and job-related benefits. On the federal level, the Great Society programs launched by President Johnson in 1965 encompassed legislative and other initiatives that came to be known as the War on Poverty, including the establishment of Medicaid and Medicare (healthcare insurance for the poor and the elderly, respectively), the Department of Housing and Urban Development, and the expansion of food stamp and youth employment programs, which favored some Latino citizens (Civil Rights 2007). Latinos protested credit and housing discrimination, school segregation, racial covenants, and freeway construction in their neighborhoods (Waldinger 1996; Diaz 2005). In the "battles against the bulldozers," they protested racially motivated redevelopment (e.g., the Temple-Baudery area in East LA) and questioned accepted notions of "blight” (Arreola 2004). The intrusion of public institutions (e.g., a proposed county prison in East LA) and infrastructure (e.g., freeways and a trash incinerator in South Central LA) into residential neighborhoods was also counteracted (Diaz 2005). Space under freeways was appropriated for parks, such as Chicano Park in Logan Heights, under the Coronado Bridge in San Diego (Ford and Griffin 1981), and Southside Park in Sacramento 
(Arreola 2004). Later on, the success of Latino communities in city incorporation led to the formalization of many “colonias” along the Mexico border (Bressi 1993).

Also, several sociopolitical forces in the 1960s-1970s helped expand Latino civil rights: federal desegregation efforts, the establishment of a national legal organization to advance Latino civil rights (the Mexican American Legal Defense and Educational Fund [MALDEF]), and the Chicano Movement (Ferg-Cadima 2004). In 1964, the Civil Rights Act, which authorized federal officials to withhold funds from states that allowed racial discrimination, extended protections to "national origin" minorities. Even though the then-Department of Health, Education, and Welfare (HEW) did little to enforce prohibitions against national origin discrimination (Wilson 2003), national origin minority claims became an alternative to "other white" claims in the Southwest. By the late 1960s, the need for a more sustained legal effort on behalf of the Latino community on several levels, including police brutality, employment discrimination, and school segregation, had become apparent (San Miguel 2001). In 1968, MALDEF, a defense organization modeled after the NAACP's legal legacy, eventually opened in San Antonio. In the early 1970s, the growing Chicano movement aimed to dislodge white privileges and improve Mexican American and Latino life through a variety of legal and political actions-boycotting public schools, rallying, negotiating with school officials, striking, and engaging in litigation efforts. For example, when the Houston school district tried to circumvent a desegregation court order by classifying Mexican American students as "white” to integrate African Americans while leaving white schools untouched, the Mexican American community responded by demanding that they be recognized as a minority group for equal protection purposes, a recognition which they obtained in 1972 (ibid).

\section{THE CONTEMPORARY LATINO CITY: 1990-2000s}

In the last two decades of the twentieth century, the seeds for a sizable, geographically dispersed Latino community have been securely planted. In 1990, the United States had 19.4 million people claiming Latino origin, a 34\% increase over the previous decade (Klitsch 1990), and making up 9\% of the population (Passel and Edomonston 1991). In 2000, that figure came to $12.5 \%$ of the population, and again increased to 14.4\% in 2005 (U.S. Census Bureau 2006). Immigration was still a strong driver of that growth, although high fertility rates also characterize the Latino community, especially the lower income strata. In 2002, 63\% of Latinos identified themselves as being foreign-born: 64\% identified Mexico as their country of origin, 9\% Puerto Rico, 7\% Central America, and 5\% both Cuba and Dominican Republic (Pew Hispanic Center/Kaiser Family Foundation 2002). By 2000, Latinos increased their share of the foreignborn population to roughly half, and the Latino foreign-born accounted for $5 \%$ of the total population, up from 3\% in 1990 (Grieco 2004). Although Mexicans continue to constitute the largest share of Hispanic immigrants, these flows have proven to be conditional on the economic health of the Unites States as the declines post-2001 and the recent increases in the last two years attest (Pew Hispanic Center 2005, 2007). Though California and Texas today retain their appeal, other destinations such as Georgia, North Carolina, and Tennessee have seen a surge in their Latino populations (Passel and Suro 2005; H. Smith and Furuseth 2006). 


\section{Conditions}

Space. Sustained immigration and natural growth maintained the Latino population increase in traditional Latino enclaves like LA, but factors such as lack of housing affordability and job accessibility (i.e., spatial mismatch between workers' skills and job requirements) prompted Latinos to move to new urban and rural locales. One of the fastest-growing ethnic populations in the country, Latino migrants are reshaping places around the United States, and particularly in the "New South" (H. Smith and Furuseth 2006). The metropolitan areas that have seen a hypergrowth of Latinos from 1980 to 2000 include Raleigh-Durham (1180\% Latino growth), Atlanta (995\%), Orlando (859\%), and Las Vegas (753\%) (Suro and Singer 2002). Three-quarters of the Latino growth in 1990-2000 occurred in neighborhoods where Latinos were a minority, bypassing existing Latino residential enclaves and thus challenging established notions of urban ethnic clustering (Lobo et al. 2002). In metropolitan LA, both newly arrived immigrants and established Latinos are moving outside the LA County, upsetting the predictions of school planners at both ends of the move, and spatially and demographically transforming the receiving white suburbs. In a general sense, the geography of Hispanic settlement is diversifying, and indeed concentration is not the norm, as only six states boast more than 1 million Latinos (Arreola 2004). Evidence exists that this process possesses no economic challenges because in their migration patterns Latinos largely compensate for white flight, and thus do not displace the native-born (Davis 2000). In some traditionally black neighborhoods, such as in South LA, Watts, and cities like Compton, racial tensions have arisen, as some blacks feel displaced by Latinos (Camarillo 2007; Irazábal and Punja 2007). Fulton (2007) claims that, in Southern California, the suburbanization patterns of previous eras is reversing-affluent people are leaving the suburbs to live in the city, and the working poor are doubling and tripling up in the suburbs to buy houses. This is especially affecting the density of Latino suburbs such as Pico Rivera, Rosemead, and Fountain Valley.

Older majority Latino neighborhoods, however, remain underserved and plagued with environmental and racial injustice (Pulido 2000; Pastor et al. 2001, 2005; Peña 2003; Pastor et al. 2005; Irazábal and Punja 2007; Sister et al. 2007). In some places, the increased geographic reach of Latinos has lead to poly-nucleation, or the rise of multiple disconnected Latino communities in the urban region, which Driever (2004) posits has a detrimental effect on the survival of group solidarity. Although this might not be relevant to larger, highly Latinized areas such as LA's Eastside, it is the case in smaller metro-areas such as Cleveland (Benedict and Kent 2004). On the other hand, the attractiveness of some Latino places rich in vernacular architecture, community festivals, and public art has hastened gentrification, as was the case in San Francisco’s Mission District (Godfrey 2004). More recently, Latino barrios have been praised by scholars and policy makers because they encompass the premises of smart growth and New Urbanism, including compact living, mixed uses, lively use of public spaces, and heavy reliance on walking and transit for transportation (Myers 2001; Méndez 2005; Irazábal and Gómez-Barris 2005, 2006b; Cisneros and Rosales 2006).

Culture. Inasmuch as the emergence of "whiteness" was a defining ethnic moment in the mid20th century, today the rise of the Latino minority as the largest in the United States - and the overall majority in some states such as in California where Latinos are expected to constitute 
52\% of the state's population by 2050 (California Department of Finance, cited in La Ganga and Lin [2007]) — has lead to an increased weariness as to what this means for the process of cultural assimilation. Critics object to multiethnic communities homogenizing to form Latino cities and neighborhoods, leaving both the effects of a legacy of discrimination and a legitimate right to self-identification unquestioned. Oversimplification is another consequence of these approaches, as in how the identification of the 1992 LA Rebellion with African Americans and Latinos' unlawful behavior masks over economic inequalities and police abuse (Valle and Torres 2000). In sum, pessimists are alarmed by a series of trends: the increased geographic reach of Latinos, persistent immigration and natural growth, and the rise of national networks of community and advocacy.

One important feature of the geographic processes of de-territorialization and re-territorialization of Latinos in the United States is that they are trans-nationalized, i.e., they draw on intense and sustained migratory flows, cultural and economic exchanges, and hybridizations across national borders. On one hand, they draw heavily on sustained immigration, especially from the smaller towns and villages in Mexico and Central America. On the other hand, immigrants help sustain (through remissions) the economies of their homelands, many of which are failing as the effects of aggressive (and often U.S. sponsored) neo-liberal policies have become manifest. The growing "Hispanic nation" in the United States also benefits from a communications revolution that makes it possible to build "communities without propinquity," which stokes fears amongst some of a potentially divisive multifaceted citizenship (Arreola 2004). These trends towards an accelerated Latinization of the United States do pose challenges to Latinos themselves. One consequence of the emergence of an over-arching Latino identity is that the diversity of the Latino population is being somewhat diluted and lost in the mainstream (Davis 2000). Also, as many young Latinos continue to lack access to good education, recreation, and job opportunities, and as they face poverty, hopelessness, and disenfranchisement, some turn to gangs. An unfortunate consequence of this is the export of gang culture back to Central America from the poor Latino neighborhoods of large industrial cities, mostly as a consequence of amendments to immigration laws, which traded repatriation of aliens with the commuting of sentences (Wolfe 2005). Gangs such as Mara Salvatrucha, a LA export, became involved in some of the most horrific prison executions, street wars, and urban terror that cities such as El Salvador (El Salvador) and Managua (Nicaragua) had ever seen (McGirk 2000; Goodale 2006). This has been particularly damaging to LA's reputation, as the tactics of these gangs are associated with a particular LA-style gang culture. Alternatively, both mainstream media (including the movie industry) and alternative media channels have progressed in the positive portrayal of Latina/o cultural icons.

Economy. In the contemporary era, Latinos face enormous challenges in their struggles to acquire the requisite competencies to participate in the knowledge-based economy. Today, the role of race relations in economic success remains pivotal. For example, the perception that Latino students reduce general educational performance in inner public schools accelerates the exodus of white families to the suburbs, which effectively starves school budgets and eliminates student body diversity (Orfield 2002). As some mid-dle-class Latinos move seeking better schooling themselves, they may be inadvertently hindering the formation of the sort of social capital ties that make for better performance, and hence retard the educational attainment necessary for workforce development (Ream 2005). This partially explains why spatially 
dispersed Salvadorans and Guatemalans fare worse than Cubans and Colombians (Bohon 2005). In California, the need for skilled labor to compensate for an aging population is not met by a failed education system, thus exacerbating a "skill mismatch" (Myers 2007). But the difficulties Latinos face in gaining entry into mixed-race neighborhoods aggravates the challenges of developing professional skills. As a larger sector of jobs becomes high-skilled, many companies follow the professional class to the suburbs. To counter these trends, planners have attempted to give incentives for minorities to obtain subsidized housing in the suburbs, attracting jobs to urban areas, or providing subsidies for transportation. These strategies, however, do not substitute for the role that building inter-and intra-ethnic social networks plays (Chapple 2006).

In the face of these hurdles, fiscal deregulation has also precipitated aspects that have been detrimental to the Latino community. The "race to the bottom," in which communities in different countries (and within the United States) compete by maintaining low factor prices, has lead to zero-sum economic competition. In many ways, the survival of low-skill labor in intensive industries such as textiles and apparel in the Southwest, and LA in particular, becomes tied to the availability of a low-wage immigrant labor force. This labor pool predominates in the "industrial core" of cities as middle-class Latinos continue their outward migration to the suburbs (Davis 2000). As globalization continues to pull U.S. industry to border regions and emerging exporting super-regions such as China, the service sector continues to support the Latino community in the contemporary American city, and Latino small businesses have become crucial to the success of the barrio (Berry and Henderson 2002). In East LA, for example, thousands of mini and strip malls built in the last two decades have changed the face of the area. This service sector specialization, however, is risky to the fortunes of Latinos long-term. Although it has spurred job creation, it has not been wholly embraced. Some have lamented that the commercial landscape has overwhelmed the urban traditional landscapes and communal spatial practices (Diaz 2005). For communities across the nation, the struggles between the defense of ethnic identity and ways of life vis-à-vis city marketization and homogenization have increased (Leclerc et al. 1999; Villa 2000; D’Avila 2004).

Of utmost importance, the international context of the global economy, and particularly the relationship of the United States with Latin America, has to be acknowledged to properly understand and address the conditions of inequality confronting Latino communities in the United States.8 A critical and broader perspective of global economics can help to develop an understanding of the relationship between socioeconomic and ethno-racial divides in the Americas and within the United States. As we do this, we can make stronger correlations among the factors that cause poverty and can contribute to devise policies that address disenfranchisement both in Latin America and within communities in the United States. Other important areas that demand greater research in the global era are the impacts of marketing and consumerism as economic and cultural practices on Latino communities, including the role of tourism and branding in the changing landscape of barrios.

Governance. In a dramatic shift from the Social Security and Great Society strategies of previous eras, in 1996 President Clinton signed the Personal Responsibility and Work Opportunity Reconciliation Act (PRWORA) — whereby needy families are no longer entitled to receive benefits, states are not required to provide assistance (even to those meeting their requirements), they must terminate benefits after a certain period of time, and must also ensure that a percentage 
of their recipients are working. According to the Department of Health and Human Services (HHS), the number of families on welfare declined from 5 million receiving AFDC benefits in 1994 to 2.6 million receiving PRWORA benefits in 1999-31\% of white and 25\% of Latino families were receiving benefits (Civil Rights 2007). The effect this has had on poorer urban Latinos cannot be underestimated.

Otherwise, another important challenge to the fortunes of Latinos today remains the issue of untapped mobilization potential. In 2000, Latino voter turnout was three times less than that of other groups. This might be because, for many Latinos, the rewards of political mobilization had not been evident (Davis 2000). In California, the increase in the population of Latinos and Latino immigrants has not been met by an increase in the Latino electorate to press for rights (Citrin and Highton 2002). Fortunately, this has been rapidly changing as of late, specifically after the increased mobilization against anti-immigrant reform proposals in Congress in 2006. The way cities have responded to the advent of gentrification is also a matter of grave importance. Gentrification becomes a serious issue when affordable and working force housing is in short supply, or when a rapid redevelopment onset leaves residents outmaneuvered and unable to adjust (Slater 2006). Displacements due to gentrification are not only precipitated by the private sector, because cities' attempts to develop infrastructure to meet gentrification pressures have also reduced the stock of affordable housing, such as in the Boyle Heights area of L.A, where low-income units were demolished to make way for public projects (DiMassa 2006a). Fiscally challenged local governments have also resorted to planning for uses such as tourism and retail, and to taxing on consumption in hotels and the like, all which increase gentrification pressures (Herzog 2004). In LA, the city council has recently made a gesture to its poorer residents, approving a moratorium on the conversion or demolition of low-cost residential hotels across the city (DiMassa 2006b) and incorporating provisions for affordable housing in the LA River Revitalization Master Plan. On the other hand, the city has increased policing in the Skid Row area populated by homeless people, mostly Latinos and other minorities, in a manner that has amounted to a criminalization of poverty (Wolch and Dear 1993).

In general, local governments continue to pursue policies that do not respond to the needs of low income Latinos, even when that is not the intent. In LA, education officials continue committing billions of dollars to building new schools in minority neighborhoods, although gentrification means that many such families have had to relocate away from these facilities (Saillant 2006). Although local job losses and changes in migration patterns are partially to blame, the skyrocketing cost of housing is the main culprit. Today, those disenfranchised and powerless remain as vulnerable as ever in an environment where equity is no longer a dominant value. Low-income Latino families continue to live precariously in cities hostile to their plight. Take, for instance, the recent example of the closure of the South Central Farm in LA. The farm on public land supported 350 immigrant poor families until it was recently re-sold to the original owner (Hopkins 2006). Partially because the owner pledged to donate a minor portion of the site for a public park, the deal was seen to be upholding the public interest, although it is clear that the basic survival needs of those families and larger community benefits of the farm were being jeopardized (Llanos 2006; Irazábal and Punja 2007). Additionally, Latinos continue to be underrepresented in large participatory planning processes to transform the landscape of LA, such as in the ongoing LA River Revitalization process (Irazábal and Eggebraten 2006). In any case, anti-immigrant sentiments in the country have had the positive effect of mobilizing many 
Latinos and Latino organizations to increase the numbers of naturalized citizens and voters. The November 2007 congressional elections saw the largest turnout of Latino voters in U.S. history, and the explicit intent of Latino voter organizations is to increase dramatically the numbers in the 2008 presidential elections (A. Gonzalez 2007).

\section{OPPORTUNITIES: ADDRESSING THE CHALLENGES OF THE CONTEMPORARY LATINO CITY}

In the contemporary city, Latinos have staved off the pressures of gentrification with certain degrees of success, as in the case of San Francisco's Mission District (Godfrey 2004). In San Antonio, Latino communities were given historic district designations, thus preserving them from development encroachments (Arreola 1988, 1995). In general, the further consolidation of a post-national or pan-Latino identity has been a boost to the fortunes of urban Latinos. This convergence, in many ways, reflects the fact that Latino communities in the United States face common challenges such as coming to terms with Americanization, developing a sense of citizenship, enduring the migratory experience, and positively utilizing aspects of transnational memory and identity (D’Avila 2004; Pescador 2004; Irazábal and Gómez-Barris 2005, 2006, 2007). Predictably, this has enabled the formation of a larger, more visible group that can better gain recognition and entitlements from the state. In the private sphere, civil society associations such as social and sports clubs (specifically soccer ones) are important venues for the reproduction of Latino culture and solidarity through their enacting of traditions, and their organization of language classes and after-work activities (Arreola 2002; Pescador 2004; Price and Whiteworth 2004). Otherwise, as a rapidly increasing minority, Latinos continue through the processes of territorializing, regulating, and symbolizing place to sustain distinctive communities flavored by ethnic business and social associations (Arreola 2002; Aguilar San Juan 2005; Irazábal and Gómez-Barris 2006, 2007). As these communities proliferate, barrio planners are looking back to historic plaza-centered villages in the Southwest (e.g., Las Vegas, NM; San Diego, TX) for inspiration, ones that are notable for their socially engaged lifestyle centered on ethnic traditions and events (Arreola 2002; J. Smith 2004). Private developers are also imitating Mexican settlements for the creation of invented places in the United States, such as Plaza Mexico in Lynwood, a city of greater LA, where Latinos can buy ethnic commodities, enact their cultural traditions (Irazábal and Gómez-Barris 2007), and even celebrate their religious rituals as if they were in Mexico (Gómez-Barris and Irazábal 2007).

Of particular interest to planners and policymakers is Latino urban living, which shows a cultural appreciation of and a familiarity with compact living, mixed use, transit usage, and socially rich public spaces. This presents a window of extraordinary opportunity for the preservation and expansion of "smart growth" communities in the United States at a moment when concerns regarding oil depletion, sustainability, and health are growing. Planners and policymakers would have to be mindful, though, that this window of opportunity decreases with the expansion of the length of stay of immigrants and with newer generations, as they increasingly adopt American customs (Irazábal and Gómez-Barris 2005, 2006b).

Economically, Latinos have also attempted to adapt to the neo-liberal economy by claiming stakes in niche industries. For example, the poultry industry in the South flourishes with and draws upon immigrant labor from beyond the established barrios (Kandel and Parrado 2004). 
Other niches include industries such as ethnic cuisine (including non-Latin American types) and apparel (Davis 2000). Some communities have managed to claim niches by building investment bridges to industries in Latin American countries, as exemplified by the relationship between Miami's Cuban American population and the financial services and media sectors in Latin America (Sassen and Portes 1993). For those relegated to the lower rungs of the economic ladder, new drives for unionization, as in the campaign to unionize hotel and homecare workers in LA, were invaluable (Valle and Torres 2000). The Latino labor uprising in LA in the last two decades also increased job stability and secured a living-wage ordinance, among other gains (Davis 2000). The emphasis of these efforts at progressively organizing the issues of the working poor has positively sensitized the general public to the plight of the Latino poor. In LA, some of the more interesting multiracial coalitions for economic opportunity, such as the LA Alliance for a New Economy (LAANE), have done just that (Pastor 2001; Hondagneu-Sotelo 2007).

Although far from being representative of the surging Latino population, the number of prominent Latino political figures has recently risen in the United States, particularly in the Southwest. Some have had important community and land-use development impacts. For example, Antonio Villaraigosa, a native East Angelino of Mexican descent, was elected mayor of LA in 2005 by a celebrated alliance of white liberals and Latinos, with about half of the city's African American vote. Because of his history as a labor advocate, the disenfranchised minorities in the city had great hopes in his performance. However, his record so far is arguably mixed, with many displeased about his handling of the South Central Farm dispute in 2006 and the police repression during the Labor Day March at McArthur Park in 2007, among other issues that have affected Latinos in the Southland. Councilman Ed Reyes, also an East Angelino and professionally trained as a planner, has led the process for the creation of the LA River Revitalization Master Plan, adopted in May 2007. The Latino governor of New Mexico, Bill Richardson, has been deeply involved in the debate for immigration reform, and is now the first Latino Democratic candidate for the primary presidential elections in 2008. As a positive trend towards gender balance, the fastest growing group of elected officials in the country is composed of Latinas (Romero 2007).

Also encouraging are demographic studies proving that as immigrants stay in the United States longer, and as they become second and third generations, they considerably improve their educational attainment levels, socioeconomic status, rate of home ownership, and other indicators of quality of life (Myers 2007). After the significant mobilizations of 2006 in favor of humane and just immigration reform, growing numbers of Latinos have naturalized and become voters, and many religious and civic organizations are providing them with support. If we consider government intervention, though, it becomes regrettably clear that its level and nature have lagged behind the pace of developments, to the detriment of urban Latinos. In what follows, we highlight how we think this should be redressed.

\section{RECAPPING AND LOOKING AHEAD: LATINO COMMUNITIES IN THE UNITED STATES}

In the prewar city, segregation and commodification, government gerrymandering, and institutionalized discrimination were the prevalent barriers Latinos faced. In the postwar city, we need to account for the added effects of suburbanization, the social criminalization of poverty, 
de-industrialization and failed economic mobility, and the government "siege" of the barrio through urban renewal and freeway construction. Today, sustained low-skilled immigration, unsatisfactory access to education and jobs, political disempowerment, xenophobic sentiments, and social exclusion remain as challenges.

Spatially, it can be said that Latino communities have had to sustain "barriological" practices in each epoch that would allow them to develop and to maintain a sense of ownership and belonging. In the past as well as today, they have defended their communities against urban renewal, the construction of freeways, and the siting of hazardous facilities. Currently, Latinos face the challenges of gentrification, thematization, commodification, and homogenization of their communities, together with a chronic deficiency of services. Culturally, the adaptation to Americanization, the challenges of a consolidating "white middle class" culture, and reservations towards an overarching Latino ethnic identification have been main battles in the struggle for recognition. In the economic sphere, the challenges of labor in the early industrial city and circumventing peripheralization in the context of a de-industrializing economy have been keenly felt. In the governance sphere, empowerment has been hampered by socio-physical control of the barrio, the capture of city government by the elite, and the challenges in the mobilization of the citizenry and electorate. Over the years, the actors in the private sphere played a pivotal role in addressing these challenges. Early on, they helped rally the community around common purposes, eventually enabling an entrepreneurial spirit in the economic realm and a cultural investment in the appropriation of place. Civil society played an important role in this early tradition of self-help, and Chicano/Latino organizations later instilled pride in the Latino heritage, facilitated the integration into the economy, and lobbied for and secured amenities.

The question about the role of government is nevertheless today as pertinent as ever, if not more so, as government interventions have had determinant roles in both creating and ameliorating conditions that dramatically and purposefully affected the quality of lives of Latino communities. In the prewar city, the major contribution was the New Deal, which through its many economic programs enfranchised the working class in a way that enabled it to achieve better social standing. In the postwar city, the federal government took the lead in the enfranchisement of minorities through civil rights legislation and Great Society programs, which also had a moderately good impact on Latino communities. Critics claim, however, that the War on Poverty amounted to little more than a call for citizen participation and that the programs had little internal coherence and financial backing. Some of the programs continue in place, but funding is less than necessary to reach eligible clients. Critics have also charged that, currently, PRWORA stresses getting jobs quickly, regardless of pay, benefits, or need for additional support services, education, or training. Latinos and other minorities are encountering great barriers when trying to leave welfare for permanent work, including transportation, childcare, and education and training needs. Race and sex discrimination and limited English proficiency are also significant limitations. Whatever the rate of success of these programs, the fact remains that economic wellbeing continues to elude a disproportionate number of Latinos, who have lower incomes and higher unemployment and poverty rates than their white counterparts (Civil Rights 2007).

Any conceptualization of the role of government needs to address the inevitable global moment, which in many ways is characterized as a series of post-nationalisms. However, national strains in the economy, labor, and the environment of the United States have fueled nationalist and 
nativist sentiments in many, which have found in immigrants in general, and Latinos in particular, the culprit of their perceived problems. A reactionary attitude against Latinos reached unprecedented heights in the 1990s as states followed California's suit and ended funding of bilingual education and social services for non-citizens, which disproportionately affected urban Latinos. Today, as immigration reform has been stalled at the federal level, some local governments across the country are discussing or enacting policies that constrict the mobility of immigrants or prevent their access to housing, jobs, education, or health care. If we consider the current discourses on immigration, economic networks, and government devolution that feed such reactionary attitudes, we argue that the federal government needs to regain control over some of these issues and discourses to bracket many of the extremist agendas at the state and local levels. At the other extreme, some cities, including LA, San Francisco, and Maywood in California, have instituted themselves as "sanctuaries" for immigrants, both in defiance of and in protest to the federal government's restrictive policies and actions, but also in deference to their majority population groups and in recognition of their contribution to their local economies and cultures.

Looking forward, we think it is imperative that the scholarship problematize the role of government in dealing with the pressing governance challenges of post-national citizenship, culture, economies, and governance. The impact of globalization on the transformation and intensification of migration patterns, economic restructuring, and international labor conditions and its spatial and economic consequences on the Latino population in the United States demands greater research, including discussion of the socioeconomic and spatial consequences of the North American Free Trade Agreement (NAFTA) agreement and other trade agreements with Latin America. Additional research should also aim to further disentangle the differential life conditions between authorized and unauthorized immigrants, and the implications for their access to adequate education, job training, job opportunities and conditions, housing, health care, and also environmental justice issues (Day 2006; Vázquez 2006; Irazábal et al. 2007). In California and elsewhere, research on Latino communities in the United States should aim to contribute to the public understanding that it is imperative for policy makers and the public at large to realize the common destiny that unites Latinos to the rest of society (Harwood and Myers 2002). This points to the need for inter-ethnic and inter-generational solidarity and the urgency of investment in education, job training, housing, health, and general well-being for the Latino population, including the newer immigrants, who will need to sustain a competitive economy in the near future as the baby boom generation retires (Myers 2007).

\section{EXPANDING PLANNING SCHOLARSHIP AND PRACTICE ON LATINO COMMUNITIES: NEW INTERDISCIPLINARY FOCI}

In addition to a greater engagement in the preceding topics, the scholarship on Latino communities can benefit from a focus on emergent geographies of globalization and crossdisciplinary research. The efforts by Herzog (2000, 2004), and Dear and Burridge (2005), to theorize the geographies of Latino urbanization in the post-NAFTA, post-border world need to be expanded. In an interesting series of studies, Herzog (2004) has taken up the question of the effects of globalization on Latino communities on both sides of the United States-Mexico border, which in his judgment amounts to a rather pessimistic "marginality on both sides.” Dear and Burridge (2005) extend this to an analysis of structural factors that fuel the urbanization of the 
"borderland." Of these, the forces of globalization, such as tourism, the commoditization of place (Irazábal and Gómez-Barris 2007), and the rise of border trade and manufacturing communities, have had a dramatic impact on the geography of border zones (Yoder and Gutierrez 2004). The unique political economy, geography, and planning challenges of the "troublesome border" between the United States and Mexico (Pezzoli 2000, 2003; Martínez 2006) are an invitation to scholarship that should not be passed up. Pressing issues include ecological degradation, social and spatial inequalities, violence, racial strife, unauthorized migration, drug smuggling, official corruption, the effects of U.S. border policing, and the economic, labor, and environmental impacts of NAFTA and the proposed Free Trade Area of the Americas (ALCA) (Arreola and Curtis 1993; Martínez 2006). Communities can no longer be understood within their regional or even national boundaries. Global issues such as immigration flows and controls, transnational cultural exchanges, and global manufacturing, distribution, and consumption patterns are inherently tied to Latinos in the United States.

We also need to account for the fact that framing research narrowly comes at the peril of losing connections to the wider literature. In this sense, the scholarship on the subject of Latino communities should not lose focus on the connections that necessarily tie it to the burgeoning literature on urban and cultural studies. Urban anthropologist Setha Low (1999) is sensitive to this fact when she argues that it is useful to think of "paradigms" or heuristic images to categorize cities. She identifies social paradigms (the ethnic, divided, gendered, and contested cities), economic paradigms (the de-industrialized, global, and informational cities), and the physical paradigms (the modernist, postmodern, and fortress cities), among others as relevant notions to conceptualize cities. Another account by urban geographer Edward Soja (2000) outlines six "discourses” on the "postmodern city.” He labels them the post-Fordist industrial metropolis, the global cosmopolis, the sprawling exopolis, the fractal city of inequalities, the carceral city of surveillance, and the SimCity of hyper-real representations, all conceptualizations that have found currency in urban studies. These lively debates illuminate general structural characteristics that urban theorists posit as driving forces of contemporary urbanization. Though in our snapshots of the prewar, postwar, and contemporary city we do not attempt any such stylization, these "images" of the city are informative of how scholars on Latino communities can connect to the larger literature.

Latinists usually approach the topic from specific disciplinary perspectives, whether history (Sanchez 1993), planning and policy (Diaz 2005), or anthropology (Arreola 1995). They also often subscribe to an epistemological tradition, whether neo-Marxism (Villa 2000), postmodernism (Herzog 2004), or populism (Acuña 1984). Nevertheless, we need to aspire to a scholarship that transcends the limitations of these ideological investments. Our scholarship needs to develop the tools to creatively engage seemingly contradictory realities, such as the dual and contemporaneous process of socioeconomic integration and informalization of immigrants. We need to account for how multiscalar processes converge in place and how global processes differentially affect a multitude of localities. For example, we argue that one aspect of understanding Latino communities today is to account for the effects of what we label a "triple disenfranchisement” many Latino immigrants face. First, a push from hometowns to border regions: the same forces of globalization that sustain United States-based rural economies have decimated the livelihoods of many Mexican and Central American villagers, forcing migrants to relocate to border communities for employment in the industrial belts of the United States- 
Mexico border. Second, migration from border regions to U.S. cities: as industrial activity in the border weakens as corporations chase lower wages in East Asia, many travel across the border seeking livelihoods. Finally, as job polarization and gentrification in U.S. cities push forward, many suffer further displacement into meager jobs and the exurban fringes.

Much of the writing on planning matters has, however, been dominated by urban theorists and historians, as this review testifies. Scholars in affiliated fields have tackled some important issues such as social construction of occupancy standards that discriminate against Latinos' preference for extended family living arrangements (Pader 2002), or the role of the informal economy in sustaining Latino communities (Valenzuela 2003). Recently, through the activism of minority planners and scholars, the APA and ACSP have acknowledged the timeliness of shaping the discourse and practice on Latino communities. The APA initiated a section on "Latinos \& Planning”' (L\&P), and ACSP has approved a "Planners of Color Interest Group” (POCIG), respectively. In this vein, we call for a literature that engages the policy discourse as much as the urban theory discourse, and thus bring scholars and practitioners into greater dialogue. The emerging debate on "Latino New Urbanism" in planning circles is one such healthy project (Myers 2001; Méndez 2005; Irazábal and Gómez-Barris 2005, 2006b; Cisneros and Rosales 2006), and the debate can only be enriched by lively discussions on Latino community development and Latino environmental justice, already a topic of interest for many scholars (Pulido 2000; Peña 2005; Irazábal and Punja 2007). In Latino communities, the attainment of place identity represents a synthesis of spatial, cultural, economic, and governance accomplishments. As such, it should constitute a crucial planning objective and a focus of community mobilization. The analysis engaged in this article prompts us to locate place identity as an explicit lesson and an ongoing locus of inquiry in the Latino community/ planning literature.

In dialogues with over 150 Latino planning practitioners and scholars, Martinez and Vazquez (2006) recently found that the issues of how planners related to Latino communities and the regulatory control thereof, among others, were high on the practicing professionals' agenda. The top six issues that this Latinos \& Planning APA Division plan to address in their first "national agenda" are: lack of participation in planning by Latinos; the relationship of planners and the planning profession to Latino communities; urban design as it relates to Latino communities; the capacity of Latino communities and organizations that serve them to engage in planning efforts; planning methods as they relate to Latino communities; and the impact of redevelopment and gentrification on Latino communities (Vazquez 2007, 2). These debates are a promising stepping stone towards an urgent and long-lasting research agenda on the part of planning scholars.

\section{NOTES}

1. We define Latino communities in this article as urban neighborhoods of majority-Latino population. Latinos are those of Hispanic descent, commonly referring to natives of Latin America and their descendents in the United States.

2. The Southwest region of the United States conventionally encompasses the five states of California, Arizona, New Mexico, Colorado, and Texas. It is considered a "homeland" of 
Mexican Americans due to the prevalence of this group in the region, its historical belonging to Mexico, and its ancestral roots for the Aztecs (Saenz et al. 2007).

3. This article cannot do justice to the variety among Latino groups in the United States. As stated, we particularly focus on Latinos in LA and the Southwest. These communities are predominantly Mexican and Mexican American. Additionally, although we acknowledge the value of comparing and contrasting the experience of Latinos with other minority racial and ethnic groups in the United States to exemplify how the Latino urban experience is unique, length constraints in this article prevents us from extensively including those. Besides, the reader can refer to considerable literature that discusses the urban experiences of other minority racial and ethnic groups in the United States, particularly those of African Americans.

4. We struggled a great deal in devising an effective way of classifying a long list of variegated materials and telling the multifaceted story of Latino communities. We could not conceive of any perfect one. Although the decision to use the categories of space, culture, economy, and governance has its drawbacks (most particularly because of the overlaps between and across categories), we nevertheless think it is a useful analytical framework because these are, from the point of view of planning relevance, the most salient dimensions of community- and placemaking.

5. Barrio, a word in Spanish, refers to delimited neighborhoods in Spanish-speaking countries, and sometimes it carries a connotation of high poverty. In the United States, it refers to Latinomajority lower-class neighborhoods. When they are big, old, and well-known, they are simply referred to as "el barrio" by locals. Such are the case of, for example, East LA, California, and Spanish Harlem in New York.

6. Named for the province in Mexico from which many of its residents immigrated, Sonoratown in downtown LA was characterized by whitewashed adobe houses and anchored by a plaza and church in the 19th and early 20th centuries.

7. Ghettos are areas where, voluntarily or involuntarily, the totality or majority of the population is of a specific group of people (usually of a racial or ethnic background, but can also be of other characteristics, such as sexual preference). The term came into widespread use during World War II to refer to Nazi ghettos where Jews were required to live (Judengasse).

8. For instance, the loans received from the International Monetary Fund and the retreat of the state in Latin American countries since the 1970s have fueled northbound immigration. Latin American countries were given these loans on the condition that they implemented "structural adjustment programs” (SAPs), including repealing laborer protections, removing agricultural subsidies for local farmers, cutting social spending, limiting regulation, privatizing public utilities, and throwing borders open to foreign imports. Meanwhile, farmers in the United States were subsidized by the government and could sell their produce cheaper than local Latin American farmers. Such policies decimated rural economies in Latin America and affected urban infrastructure as millions of people from rural areas flooded into the cities. They usually occupied land subject to landslides and other disasters. The conjunction of natural and social 
factors further weakened these economies, and thus many people migrated north as global economic refugees.

\section{REFERENCES}

Acuña, R. 1984. A community under siege: A history of Chicanos east of the Los Angeles River. Los Angeles: Chicano Studies Research Center, Publications, University of California at Los Angeles.

Aguilar San Juan, K. 2005. Staying Vietnamese: Community and place in Orange County and Boston. City and Community 4:37-66.

Arreola, D. 1988. Mexican American housescapes. Geographical Review 78:299-315.

—. 1995. Urban ethnic landscape identity. Geographical Review 85:518-34.

—. 2002. Tejano South Texas: A Mexican American cultural province. Austin: University of Texas Press.

ed. 2004. Hispanic spaces, Latino places: Community and cultural diversity in contemporary America. Austin, TX: University of Texas Press.

Arreola, D., and J. Curtis. 1993. The Mexican border cities: Landscape anatomy and place personality. Tucson: University of Arizona Press.

Avila, E. 2004. Popular culture in the age of white flight: Fear and fantasy in suburban Los Angeles. London: University of California Press.

Barry, T., L. Carlsen, and J. Gershman. 2005. The Good Neighbor Policy: A history to make us proud. The International Relations Center. http://www.irc-online.org/content/pdf/0503ggn.pdf (accessed July 4, 2007).

Benedict, A., and R. Kent. 2004. The cultural landscape of a Puerto Rican neighborhood in Cleveland, Ohio. In Hispanic spaces, Latino places: Community and cultural diversity in contemporary America, ed. D. Arreola, 187-205. Austin, TX: University of Texas Press.

Berry, K., and M. Henderson. 2002. Geographical identities of ethnic America: Race, space, and place. Reno: University of Nevada Press.

Bohon, S. 2005. Occupational attainment of Latino immigrants in the United States. The Geographical Review 95 (2): 249-66.

Booza, J., J. Cutsinger, and G. Galster. (Report) June 2006. Where did they go? The decline of middle-income neighborhoods in metropolitan America. Washington, DC: Brooking Institution. 
Bressi, T. W. 1993. Plaza, parque, colonia. Places: A Quarterly Journal of Environmental Design 8 (3): 91-3.

Camarillo, A. 1979. Chicanos in a changing society: From Mexican pueblos to American barrios in Santa Barbara and Southern California. Cambridge, MA: Harvard University Press.

- 2007. Going back to Compton: Reflections of a native son on life in an infamous American city. Unpublished book manuscript.

Canton, D. 2004. Ethnic, race, and coalition politics in postindustrial urban America. Journal of Urban History 30 (4): 616-26.

Castells, M. 1977. The urban question: A Marxist approach. Cambridge, MA: MIT.

Chapple, K. 2006. Overcoming mismatch: Beyond dispersal, mobility, and development strategies. Journal of the American Planning Association 72 (3): 322-36.

Cisneros, H., and J. Rosales, eds. 2006. Casa y Comunidad: Latino Home and Neighborhood Design. Builder Books.

Citrin, J., and B. Highton. 2002. How race, ethnicity and immigration shape the California Electorate. Public Policy Institute of California.

http://www.ppic.org/content/pubs/R_1202JCR.pdf (accessed November 22, 2006).

Civil Rights Coalition for the 21st Century. 2007. Race, class, and economic justice. http://www.civilrights.org/research_center/ civilrights101 (accessed July 4, 2007).

Cuéllar, C. E. 2003. Stories from the barrio: A history of Mexican Fort Worth. Fort Worth, Texas: TCU Press.

Curtis, J. 2004. Barrio space and place in South East Los Angeles, California. In Hispanic spaces, Latino places: Community and cultural diversity in contemporary America, ed. D. Arreola. Austin, TX: University of Texas Press.

D’Avila, A. 2004. Barrio dreams: Puerto Ricans, Latinos, and the neo-liberal city. Berkeley: University of California Press.

Davis, M. 2000. Magical urbanism: Latinos reinvent the U.S. City. London, New York: Verso.

Day, K. 2006. Anti-immigrant agendas and fear in city planning: The case of Costa Mesa, California. Paper presented at Association of Collegiate Schools of Planning (ACSP) 47th Annual Conference "Borders and Cores: What is planning in the global era?” Fort Worth, TX, November 9-12.

Dear, M., and A. Burridge. 2005. Cultural integration and hybridization at the United StatesMexico Borderlands. Cahiers de Géographie du Québec vol. 49 (138): 301-18. 
Diaz, D. 2005. Barrio urbanism: Chicanos, planning, and American Cities. New York and London: Routledge.

DiMassa, C. M. 2006a. Los Angeles Times, July 23, California, Metro, Metro Desk, Part B; p. 4.

—. 2006b. Los Angeles Times, May 11, California, Metro, Metro Desk, Part B; p. 1.

Dogadag, T. 1974. Spatial control and public policies: the example of Mexican American housing. Professional Geographer 26 (3): 262-69.

Dohan, D. 2003. The price of poverty: Money, work, and culture in the Mexican American barrio. Berkeley: University of California Press.

Donato, R. 1997. The other struggle for equal rights: Mexican Americans during the civil rights era. Albany: State University of New York Press.

Driever, S. 2004. Latinos in polynucleated Kansas City. In Hispanic spaces, Latino places: Community and cultural diversity in contemporary America, ed. D. Arreola. Austin, TX: University of Texas Press.

Espinosa, G., V. Elizondo, and J. Miranda. 2005. Latino religions and civic activism in the United States. Oxford: Oxford University Press.

Ferg-Cadima, J. 2004. Black, white and brown: Latino school desegregation efforts in the preand post-Brown v. Board of Education era. Mexican American Legal Defense and Educational Fund (MALDEF). http://www.maldef.org/publications/pdf/Latino DesegregationPaper2004.pdf (accessed July 8, 2007).

Ford, L., and E. Griffin. 1981. Chicano park: Personalizing an institutional landscape. Landscape 25 (2): 42-8.

Frankenberg, E., and C. Lee. 2002. Harvard civil rights project, Race in American Public Schools: Rapidly Resegregating School Districts.

Frausto, T. Y. 1999. El Movimiento: The Chicano social project since 1960. In La vida Latina en LA: Urban Latino cultures, eds. G. Leclerc,

R. Villa, and M. Dear, 23-34. Thousand Oaks: Sage.

Fuchs, L. 1990. The American kaleidoscope: Race, ethnicity and the civic culture. Hanover, NH: University Press of New England.

Fulton, W. 1997. The reluctant metropolis: The politics of urban growth in Los Angeles. Baltimore: The Johns Hopkins University Press.

—. 2007. Trading places. Los Angeles Times, July 29. 
Gans, H. 1968. Culture and class in the study of poverty. In On Understanding Poverty: Perspectives from the Social Sciences, ed.

D. P. Moynihan, 201-28. New York: Basic Books.

García Bedolla, L. 2005. Fluid borders: Latino power, identity, and politics in Los Angeles. Berkeley: University of California Press.

García, M. C. 2005. Dangerous times call for risky responses: Latino immigration and sanctuary, 1981-2001. In Latino religions and civic activism in the United States, eds. G. Espinosa, V. Elizondo, and J. Miranda, 159-75. New York: Oxford University Press.

Gibson, C. 1992. The contribution of immigration to the growth and ethnic diversity of the American population. Proceedings of the American Philosophical Society 136 (2): 157-75.

Gilbert, L. 2001. Identity, pluralism and urbanity: Negotiating (ethno)national identity and diversity: Québécois/es in Montréal and Chicanos/as in Los Angeles, PhD diss., University of California, LA.

Godfrey, B. 2004. Barrio under siege: Latino sense of place in San Francisco, California. In Hispanic spaces, Latino places: Community and cultural diversity in contemporary America, ed. D. Arreola, 79-102. Austin, TX: University of Texas Press.

Gómez-Barris, M., and C. Irazábal 2007. Religion moves to the mall: The mobilization of Hispanic religiosity in Plaza Mexico.” Paper presented at the Latin American Studies Association Conference, Montreal, Canada. September.

Gonzalez, A. 2007. Speaker address at the Latino Vote Banquet of the Southwest Voter Registration Education Project. Los Angeles Cathedral Plaza, July 13.

Gonzalez, G. 1990. Chicano education in the era of segregation. Cranbury, NJ: Associated University Presses.

Gonzalez, R. 1999. Learning from East LA. In La Vida Latina en LA: Urban Latino cultures, eds. G. Leclerc, R. Villa, and M. Dear, 185-198. Thousand Oaks: Sage.

Goodale, G. 2006. LA's latest export: gangs. The Christian Science Monitor. http://www.csmonitor.com/2006/0210/p15s01-altv. html?s=hns (accessed February 10, 2006).

Grieco, E. 2004. The foreign-born from Mexico in the United States: 1960 to 2000. Proceedings of March 29 conference. Division of United States Studies and Mexico Institute, Woodrow Wilson International Center for Scholars: The Migration Policy Institute. http://www.wilsoncenter.org/topics/pubs/HispChall.PDF (accessed January 15, 2007).

Griswold del Castillo, R., and A. de León. 1996. North to Aztlán: A history of Mexican Americans in the United States. New York: Twayne Publishers. 
Harvey, D. 1998. Social justice and the city. Malden, MA: Blackwell Publishing. 1999. The limits to capital. London: Verso.

Harwood, S., and D. Myers. 2002. The dynamics of immigration and local governance in Santa Ana: Neighborhood activism, overcrowding, and land-use policy. Policy Studies Journal 30 (1): 70-92.

Hempstead, K. 2007. Mobility of the foreign-born population in the United States, 1995-2000: The role of gateway states. The International Migration Review 41 (2): 466-80.

Herzog, L., ed. 2000. Shared space: Rethinking the U.S.-Mexican Border. La Jolla: Center for U.S.-Mexican Studies, 41-74.

Herzog, L. 2004. Globalization of the barrio: Transformation of the Latino cultural landscapes of San Diego, California. In Hispanic spaces, Latino places: Community and cultural diversity in contemporary America, ed. D. Arreola, 103-24. Austin, TX: University of Texas Press.

Hondagneu-Sotelo, P., ed. 2007. Religion and social justice for immigrants. Rutgers University Press.

Hopkins, B. 2006. The Daily News of Los Angeles, June 14. Valley Edition, News; N1.

Huntington, S. 2004. Who are we?: The challenges to America's identity. New York: Simon \& Schuster.

Irazábal, C., and G. Dyrness. 2007. Promised lands: Space, religion, and social justice for immigrants in Southern California. Paper presented at the Association of Collegiate Schools of Planning (ACSP) 48th Annual Conference "Building Ladders to the Middle Class." Milwaukee, Wisconsin, October 18-21.

Irazábal, C., and S. Eggebraten. 2006. The emperor’s new clothes: Covert reassertion of the rational planning model in the Los Angeles River revitalization process. Paper presented at the Association of Collegiate Schools of Planning (ACSP) 47th Annual Conference "Borders and Cores: What is planning in the global era?” Fort Worth, TX, November 9-12.

Irazábal, C., and M. Gómez-Barris. 2005. Latino New Urbanism: Reformulations of urban practices and living preferences in Los Angeles. Association of Collegiate Schools of Planning (ACSP) 46th Annual Conference “Beyond the City Beautiful.” Kansas, Missouri, October 27-30.

. 2006. Latino new urbanism in Los Angeles. Paper presented at the Latin American Studies Conference, San Juan, Puerto Rico, March.

- 2006a. Bounded tourism: Immigrant politics, consumption, and traditions at Plaza Mexico, Journal of Transcultural Change 5:1-28. 
Irazábal, C., L. Pulido, and G. Dyrness. 2007. Struggles for immigrant (dis)integration: Regulation and appropriation of urban space by/for/against immigrants in Southern California. Working paper.

Irazábal, C., and A. Punja. 2007. Cultivating just planning and legal institutions: A critical assessment of the South Central Farm in Los Angeles. Paper presented at the Association of Collegiate Schools of Planning (ACSP) 48th Annual Conference. October.

Jaret, C. 1983. Recent neo-Marxist urban analysis. Annual Review of Sociology 9:499-525.

Kandel, W., and E. Parrado. 2004. Hispanics in the American South and the transformation of the poultry industry. In Hispanic spaces, Latino places: Community and cultural diversity in contemporary America, ed. D. Arreola, 255-76. Austin, TX: University of Texas Press.

Klitsch, M. 1990. Hispanic fertility rate 40 percent higher than rate of non-Hispanics. Family Planning Perspectives 22 (3): 136-37.

La Ganga, M., and S. Lin. 2007. 60 million Californians by mid-century. Los Angeles Times, July 10. http://www.latimes.com/ news/local/la-me-population10jul10,0,1878846.story?coll= lahome-center (accessed July 11, 2007).

Leclerc, G., R. Villa, and M. Dear, eds. 1999. La Vida Latina en LA: Urban Latino cultures. Thousand Oaks: Sage.

Lefebvre, H. 1974. The production of space. Malden, MA: Blackwell Publishing.

Light, I. 2004. Immigration and ethnic economies in giant cities. International Social Science Journal 56 (181): 385-98.

Llanos, C. 2006. The Daily News of Los Angeles, July 27. Valley Edition, News; N4.

Lobo, A., P. Flores, J. Ronald, and J. Salvo. 2002. The impact of Hispanic growth on the racial/ethnic composition of New York City neighborhoods. Urban Affairs Review 37 (5): 703 27.

Low, S., ed. 1999. Theorizing the city: The new urban anthropology reader. New Brunswick, NJ: Rutgers University Press.

Lunday, E. A. 2005. Ethni-city: Latino new urbanism and the future of the American city. Urban Land, 64 (10): 73-77.

Martinez, A., and L. Vazquez. 2006. Draft national agenda for Latinos and planning. Paper presented at the American Planning Association Conference, San Antonio, TX, October.

Martínez, O. 2006. Troublesome border. Rev. ed. Tucson: University of Arizona Press. 
Massey, D. 1995. The new immigration and ethnicity in the United States. Population and Development Review 21 (3): 631-52.

—. 2005. For space. Thousand Oaks, CA: Sage Publications.

Massey, D., and K. Schnabel. 1983. Recent trends in Hispanic immigration to the United States. International Migration Review 17 (2): 212-44.

McGirk, T. 2000. Gang-bangers: A deadly U.S. export. http://www .rense.com/general5/gang.htm (accessed November 11, 2006).

Méndez, M. 2005. Latino New Urbanism: Building on cultural preferences. Opolis 1 (1): 33-48.

Michelson, M. R. 2003. The corrosive effect of acculturation: How Mexican Americans lose political trust. Social Science Quarterly 84 (4): 918-34.

Mollenkopf, J. 1983. The contested city. Princeton, NJ: Princeton University Press.

Montoya, M. 2001. A brief history of Chicana/o school segregation: One rationale for affirmative action, 12. La Raza Law Journal 159, 163.

Moore, J., and R. Pinderhughes, eds. 1993. In the Barrios: Latinos and the underclass debate. New York: Russel Sage Foundation.

Myers, D. 2001. Demographic futures and a guide to planning. California's Latinos and the compact city. APA Journal 67 (4): 383-97.

- 2007. Immigrants and boomers: Forging a new social contract for the future of America. New York: Russell Sage Foundation.

Nostrand, R. 1970. El Cerrito revisited. New Mexico Historical Review 57 (2): 109-22.

Orfield, G., and S. Eaton. 1996. Dismantling desegregation: The quiet reversal of Brown v. Board of Education. New York: The New Press.

Orfield, M. 2002. American metropolitics: The new suburban reality. Brookings Institution Press.

Pader, E. 2002. Housing occupancy standards: Inscribing ethnicity and family relations on the land. Journal of Architectural and Planning Research 19 (2): 300-18.

Passel, J. S., and R. Suro. 2005. Rise, peak, and decline: Trends in U.S. Immigration 1992-2004. Pew Hispanic Center. A Pew Research Center Project http://www.ilw.com/articles/2005,1205passel .pdf (accessed January 5, 2007). 
Passel, L., and J. Edomonston. 1991. Immigration and race: Recent trends in immigration in the United States. Paper presented at a conference on immigration and ethnicity: The integration of America’s newest immigrants, held at the Urban Institute, Washington D.C. June 17-18.

Pastor, M., J. Sadd, and J. Hipp. 2001. Which came first? Toxic facilities, minority move-ins, and environmental justice. Journal of Urban Affairs 23 (1): 3.

Pastor, M., J. Sadd, and R. Morello-Frosch. 2005. The air is always cleaner on the other side: Race, space, and air toxics exposures in California. Journal of Urban Affairs 27 (2): 127-48.

Pastor, M. 2001. Common ground at ground zero? The new economy and the new organizing in Los Angeles. Antipode 33 (2): 260-89.

Peña, D. 2003. The scope of Latino/a environmental studies. Latino Studies 1:47-78.

— 2005. Mexican Americans and the environment: Tierra y Vida. University of Arizona Press.

Perea, J. 1997. The black/white binary paradigm of race: The "normal science" of American racial thought, 85 Calif. L. Rev. 1213, 1250.

Pescador, J. J. 2004. ¡Vamos Taximaroa! Mexican/Chicano soccer associations and transnational/translocal communities, 1967-2002. Latino Studies 2 (3): 352-78.

Pew Hispanic Center. 2005. Rise, peak, and decline: Trends in U.S. immigration 1992-2004. Published September 2005. http:// pewhispanic.org/files/execsum/53.pdf (accessed July 10, 2007).

—. 2007. Indicators of recent migration flows from Mexico. Published May 2007. http://pewhispanic.org/files/factsheets/ 33.pdf (accessed July 10, 2007).

Pew Hispanic Center/Kaiser Family Foundation. 2002. National Survey of Latinos. Published Dec. 2002. http://pewhispanic.org/ files/execsum/15.pdf (accessed July 10, 2007).

Pezzoli, K. 2000. From pollution prevention to industrial ecology. In Shared space: Rethinking the U.S.-Mexican border, ed. L. Herzog, 41-74. La Jolla: Center for U.S.-Mexican Studies.

Pezzoli, K. 2003. Enabling comprehensive regional planning in the San Diego-Tijuana global city-region, section. GPEIG Newsletter, Spring 2003.

http://www.regionalworkbench.org/files/GPEIG/ GPEIGnewsletterSpring03.pdf (accessed June $21,2006)$.

Price, M., and C. Whiteworth. 2004. Soccer and Latino cultural space: Metropolitan Washington Fútbol Leagues. In Hispanic spaces, Latino places: Community and cultural diversity in contemporary America, ed. D. Arreola, 167-86. Austin, TX: University of Texas Press. 
Pulido, L. 2000. Rethinking environmental racism: White privilege and urban development in Southern California. Annals of the Association of American Geographers 90 (1): 12-40.

Rangel, J., and C. Alcala, 1972. Project report: De Jure segregation of Chicanos in Texas schools, 7 Harv. C.R.-C.L. L. Rev. 307, 308.

Ream, R. 2005. Toward understanding how social capital mediates the impact of mobility on Mexican American achievement. Social Forces 84 (1): 201-24.

Rodriguez, N. 1993. Economic restructuring and Latino growth in Houston. In In the Barrios: Latinos and the underclass debate, eds.

J. Moore, and R. Pinderhughes, 101-28. New York: Russel Sage Foundation.

Rodriguez, S. 2001. Fiesta time and plaza space: Resistance and accommodation in a tourist town. Journal of American Folklore III (439): 39-56.

Rojas, J. 1999. The Latino use of urban spaces in East Los Angeles. In La Vida Latina en LA: Urban Latino cultures, eds. G. Leclerc, R. Villa, and M. Dear, 131-38. Thousand Oaks: Sage.

Romero, G. 2007. Speaker address at the Latino Vote Banquet of the Southwest Voter Registration Education Project. Los Angeles Cathedral Plaza, July 13.

Romo, R. 1983. East Los Angeles: History of a barrio. Austin: University of Texas Press.

Ruiz, V. 2003. We always tell our children they are Americans: Méndez v. Westminster and the California road to Brown v. Board of Education. College Board Review 200:21-27.

Saenz, R., C. Cready, and M. C. Morales. 2007. Adios Aztlan: Mexican American out-migration from the Southwest. In The Sociology of Spatial Inequality, eds. L. Lobao, G. Hooks, and A. Tickamyer, 189-214. Albany, NY: State University of New York Press.

Saillant, C. 2006. Fewer pupils create more worries. Los Angeles Times, July 31, California, Metro, Metro Desk, B1.

San Miguel, G. 2001. Brown, not white: School integration and the Chicano movement in Houston. Houston: Texas A\&M University Press.

Sanchez, G. 1993. Becoming Mexican American: Ethnicity, culture, and identity in Chicano Los Angeles, 1900-1945. New York: Oxford University Press.

Sassen, S., and A. Portes. 1993. Miami: A new global city? Contemporary Sociology 22 (4): $471-77$.

Sister, C., J. Wolch, J. Wilson, A. Linder, M. Seymour, J. Byrne, and 
J. Swift. 2007. Green Visions Plan for 21st century Southern California.

14. Park and Open Space Resources in the Green Visions Plan Area, University of Southern California GIS Research Laboratory and Center for Sustainable Cities, Los Angeles, California.

Slater, T. 2006. Los Angeles Times, July 30, Current, Editorial Pages Desk, M1.

Smith, H., and O. Furuseth. 2006. Latinos in the new South: Transformations of place. Hampshire, UK: Ashgate.

Smith, J. 2002. Cultural landscape change in a Hispanic region. In Geographical identities of ethnic America: Race, space, and place, eds.

K. A. Berry and M. L. Henderson, 174-200. Reno: University of Nevada Press.

- 2004. The Plaza in Las Vegas, New Mexico: A community gathering place. In Hispanic spaces, Latino places: Community and cultural diversity in Contemporary America, ed. D. Arreola, 39-53. Austin, TX: University of Texas Press.

Smith, M. P. 1992. Postmodernism, urban ethnography, and the new social space of ethnic identity. Theory and Society 21 (4): 493-531.

Soja, E. 2000. Postmetropolis: Critical studies of cities and regions. Malden, MA: Blackwell.

Suro, R., and A. Singer. 2002. Latino growth in metropolitan America: Changing patterns, new locations. Washington, DC: The Brooking Institute.

U.S. Census Bureau. 2006. National population estimates. May 10 estimate. http://www.infoplease.com/ipa/A0762156.html (accessed July 10, 2007).

Valenzuela, A., Jr. 2003. Day labor work. Annual Review of Sociology 29:307-34.

Valle, V., and R. Torres. 2000. Latino metropolis. Minneapolis: University of Minnesota Press.

Vazquez, L. 2007. Message from the Division Chair Leonardo Vazquez, AICP/PP. Latinos \& Planning Newsletter: A Division of the American Planning Association (APA). February Volume 1, Issue 1, p. 2.

Vázquez, T. 2006. "Borders, immigration, and the economy.” Association of Collegiate Schools of Planning (ACSP) 47th Annual Conference "Borders and Cores: What is planning in the global era?” Fort Worth, TX, November 9-12.

Villa, R. H. 2000. Barrio-Logos: Space and place in urban Chicano literature and culture. Austin: University of Texas Press. 
Waldinger, R. 1996. Still the promised city: African-Americans and new immigrants in postindustrial New York. Cambridge, MA: Harvard University Press.

Waldinger, R., and M. Bozorgmehr, eds. 1996. Ethnic Los Angeles. New York: Russel Sage Foundation.

Wild, M. 2005. Street meeting: Multiethnic neighborhoods in early twentieth century Los Angeles. Berkeley: University of California Press.

Wilson, S. 2003. Brown over “other white”: Mexican Americans’ legal argument and litigation in school desegregation lawsuits 21 Law \& Hist. Rev. 145, 152.

Wolch, J., and M. Dear. 1993. Malign neglect: Homelessness in an American City. Jossey Bass Wiley.

Wolfe, A. 2005. Central America's street gangs are drawn into the world of geopolitics. Power and Interest News. http://www .pinr.com/report.php?ac=view_report\&report_id=354\& language_id=1 (accessed November 14, 2006).

Wollenberg, C. 1976. All deliberate speed: Segregation and exclusion in California schools, 1855-1975.

Yoder, M., and R. de Gutiérrez. 2004. Social geography of Laredo, Texas, neighborhoods: Distinctiveness and diversity in a majority-Hispanic place. In Hispanic spaces, Latino places: Community and cultural diversity in contemporary America, ed. D. Arreola, 55-76. Austin: University of Texas Press. 